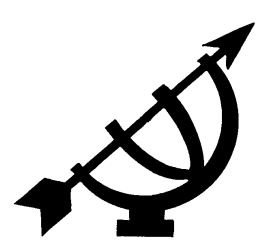

\title{
Calling and resistance: Huldrych Zwingli's (1484-1531) political theology and his legacy of resistance to tyranny
}

\author{
A.W.G Raath \& S.A. de Freitas \\ Department of Constitutional Law and Jurisprudence \\ University of the Free State \\ BLOEMFONTEIN \\ e-mail: raatha@rs.uovs.ac.za \\ defreits@rd.uovs.ac.za \\ Abstract
}

Calling and resistance: Huldrych Zwingli's (1484-1531) political theology and his legacy of resistance to tyranny

Huldrych Zwingli's ground-breaking contribution to Reformational political theory has not been accorded the necessary exposure that it deserves. Zurich and Genevan Reformational thought during the fifteenth century owed much of its political insight to Zwingli's expositions pertaining to the functions of the offices of magistracy and ministry, as well as on resistance theory. Zwingli also heralded the idea of the Christian community, in which church and society are not to be viewed as two separate entities - the view that the Christian nation is both church and political community under the rule of God. Not only was this inheritance of Zwingli's thought limited to the continent but it also manifested itself in the English and Scottish Reformational worlds. Consequently, this article serves as a reminder that the more familiar proponents of early Reformational thought (in the context of Reformational political expositions) such as Heinrich Bullinger, and to a lesser degree John Calvin, were preceded and influenced by the legacy of Huldrych Zwingli's Reformational political theology.

\section{Introduction}

By the opening years of the sixteenth century, absolute monarchy was becoming the prevailing type of government in Western Europe. Medieval institutions were transformed into structures supporting ideas of absolute monarchy. The church itself fell prey to these monarchistic tendencies, and became a partner of national government. The rise of Monarch- 
ism, absolutism, and the consolidation of political power demanded clarity on the issues of political tyranny and the abuse of political power. The Swiss Reformer, Huldrych Zwingli's political theology exercised a strong influence in Europe and England. Not only did he formulate an alternative approach to secular politics, but he also reacted sharply to the idea of unlimited government on a secular basis. All the key-elements of later Reformational political thought can be traced to the work performed by Zwingli, who can therefore rightfully be regarded as the father of Reformational political thought. These elements were carried over by Heinrich Bullinger and John Calvin into the political traditions of English and Scottish Reformational thinking as well as into the world of Reformational politics in Europe. ${ }^{1}$

- Zwingli was firstly responsible for developing the Reformational political perspective within the framework of the covenant.

- Secondly, Zwingli formulated the differences between spiritual and civil government.

- Thirdly, he distinguished between the office and the person of the magistrate.

- Fourthly, he made provision, theoretically, for the principle of removing tyrants from office.

Included in Zwingli's covenantal thought was the high degree of man's responsibility to follow the ways of the Lord, an understanding that would lead to Zwingli's emphasis on resistance theory. Bullinger extended Zwingli's understanding of the covenant as a framework for a Reformational political perspective. This covenantal thought was further developed by Bullinger into a new approach to political theology generally, and although Calvin referred to the covenant, he did not develop it into a systematic key for understanding Scripture as a whole. Bullinger extended Zwingli's formulations concerning both the relationship between spiritual and civil government as well as the Biblical idea of magisterial office. Pertaining to Zwingli's resistance theory, Bullinger's views on this issue reflected the same unclear descriptions of the

1 It is also interesting to note that the general structure of Bullinger's influential Decades (not unlike that of the more famous Institutes of Calvin, and the fifth and final Decade, like the fourth book of the Institutes), is devoted to such doctrinal themes as the church, the ministry, prayer, and the dominical sacraments. The Decades includes two sermons on the Church, the first and more important on its nature and characteristics, the second on its unity as the body or bride of Christ and the mother of all true believers. In the latter sermon it is noteworthy that Bullinger, like Calvin, attributes a high sense of dignity to the church and has a keen awareness of the dangers of schism (cf. Bromiley, 1953:285). 
circumstances under which tyrants could be removed from office ultimately giving rise to two distinct approaches to resistance to tyranny. Different from both Luther and Calvin, who stood on substantially identical ground relative to the fundamental moral issue, it was in particular Bullinger's work, Decades, that played a most important role in shaping the views of Reformational authors in both England and Scotland and that was supplemented by his vast correspondence with Reformational theologians in both these countries. ${ }^{2}$

Zwingli's views on magistracy and politics also decisively shaped the political views of the Genevan Reformer John Calvin. Similar to Bullinger, Calvin also accepted the following aspects on Zwingli's views: the differences between spiritual and civil government; the principle of the office of magistracy being ordained by God and his appealing against the so-called "Christian" denial or rejection of magistracy. Furthermore Calvin also accepted the principle that magistrates should be faithful as God's deputies and perform their duties subject to both tables of the law of God, and, although he did not subscribe to active resistance to tyranny, he did accept the principle that God sometimes intervenes by unwitting agents. The influence of Zwingli on Calvin was also carried forward into the English and Scottish worlds by Calvin's systematic theological expositions in his Institutes and abridgements of this work.

This article will, however, focus on the contribution of Zwingli and Bullinger to Reformational political theory and the fact that English and Scottish Reformational thought on the resistance to tyranny, although

2 Bullinger's Decades was particularly influential in Reformational circles in these countries. The first two decades appeared in one volume in 1549. The third and fourth constituted a second volume in 1550, and the fifth and concluding decade was published in 1551. A folio edition of the completed series was prepared in 1552, and translations were made fairly quickly, not only into English, but also into German, Dutch and French. G.W. Bromiley (1953:283), responsible for translations of a selection of works by Zwingli and Bullinger, with introductions and notes, The Library of Christian Classics, points out the close interconnection between the Decades and the Reformation in England. The ninth sermon of the second decade was translated and published in the year of its appearance, and the translation included a dedication to Edward VI. This sermon dealt with magistracy and obedience to the office of magistrates. The translation was by Walter Lynne. Bullinger himself dedicated the two parts of the second volume to Edward, and the translation of the first of these was set in hand at once. The work was done by Thomas Caius. The third volume also had an English dedication, this time to Lord Grey. The translation of the whole series of the Decades was not completed until later in the century, but there were three successive editions of this translation (in 1577, 1584 and 1587). The work was esteemed so highly by Elizabethan leaders, says Bromiley (1953:283), that at the instigation of Whitgift, it was granted a quasi-authoritative position as the theological text-book of unlicensed ministers. 
based solidly on the legacy of the Swiss Reformation, reflect essential differences on issues pertaining to the resistance to tyranny.

\section{Covenant and the Christian community}

Zwingli is the father of the Reformational principle of the covenant. He found in the Bible the existence of the "same testament and covenant" (Z:VII 164.2-165.1, 168.33-35, 169.4-6, 8-11); that is, the same mercy of God promised to the world through his Son - the mercy that saved Adam, Noah, Abraham, Moses and David saved also Peter, Paul, Ananias, Gamaliel, and Stephen. It is one and the same testament which God had with the human race from the foundation of the world to its dissolution; the one and eternal covenant from before man was formed, so there could be no other testament than that which furnished salvation through Jesus Christ (Z:VII 164.2-165.1, 168.33-35, 169.4-6, 8-11).

As early as 1525 Zwingli saw the sacraments as signs of the covenant of grace made by God with man, that He will be their God and they will be His people (Z:IV 499.1-502.5). According to Zwingli baptism serves the purpose that circumcision did in the Old Testament, namely that those who trust in God should lead their children to know God and cling to him (Z: IV 292.4-295.33). In expounding God's covenant with Abraham, Zwingli sees the covenantal sign of baptism in terms of our pledge pledging oneself and pledging to bring up one's children in the ways of the Lord. Children are obliged to live in a Christain way and parents to bring them up in a Christian way - a situation that would not follow if the children were not baptized (Z:IV 500.9-39). 3 However, the covenant is God's covenant of grace, rather than our covenant, His promise rather than ours, and the sign of the covenant as God's sign of his covenant and promise, rather than our pledge to live a godly life. But essentially this covenant is not a new or different covenant, but we are included in the same covenant that God made with Abraham (Z:IV 596.1-2, 636.24$6,636.33-637.1$ ). The covenant is God's promise to be our God and the God of our seed and also to send a saviour of the seed of Abraham (Z:630.24-632.25).

The importance of baptism for the Christian community lies in the fact that this sacrament serves as the device for enrolling in the people of God; an outward covenant sign that all should receive who are included in the covenant (Z:IV 593.5-6, 618.13-16). The importance of Zwingli's views on baptism as sign of the covenant and his views on the Christian developed separately from the issues connected with baptism. 
community are of fundamental importance for understanding his theology of the Christian community: there is no other covenant but this one covenant between God and his people. God has included us into the same covenant that He made in Old Testament times, so that we might be one church and people with them. 4

Already in 1524 he linked the idea of community and mutual commitment to the ministration of the sacraments: the eucharist is seen as the inward and outward union of Christian people,

- "in which we 'testify to all men that we are one body and one brotherhood' and in which we renew our brotherhood."

- "Christ wills that his own shall be one, just as he is one with the Father, and for this union he has given us the sacrament ...",

- "And as he gave himself for us, we also are bound to give ourselves one for the other, as for one's brother, indeed as for one's own member" (Z:III 124.27-125.15, 26). 5

The important thing about the Zwingli's theology is that the covenant entails that God is our God and we his people - the covenant made with the people of Israel was made with all the people, including the children, and through this people the covenant will extend to all peoples. In addition to this, Zwingli sees God's fundamental concern with unity God willed that all men be descended from one father, for the sake of unity; God created man in his own image, so that just as the three persons are one God, who cannot be in disharmony with himself, so also the life of men might be peaceful and united. God's purpose in creation and regeneration is unity - we are to be one body, whose head is Christ (Z:I 167.14-169.4).6 This unity in the community of the church also

4 The words of Christ in Matthew 8:11, as do passages in Romans 11, Ephesians 2:1120, Hebrews 12:22-24, and 1 Peter 2:9-10, are particularly instructive on this point in Zwingli's theology. (Also cf. Z:IV I 156.39-41, 169.4-6, 164.2-4, 163.8-19, 164.7-11, 165.3-16, 166.3-5, 166.13-168.31.)

5 Stephens (1986:225 note 21) points out the importance of 1 Corinthians 10:16-17 in Zwingli's thought and the sense of pledge or covenant in which we pledge ourselves to each other, which are evident in other writings of the period (Z:III 227.11-228.28, 282.16-32; VIII 208.19-23). Also cf. (Z:III 282.29-32), "Ad hoc enim posita est, ut simul eundem cibum edentes, hoc est fide, quae est in Christo Jesu, in unum corpus coaliti, hac sacra velut initione et sacramento in unum exercitum et peculiarem dei populum uniamur."

$6 \quad$ Moeller (1972:87-90), brings Zwingli's strong views on the Christian community in his writings on the church and the sacraments into relation with his being part of an urban community. 
extended to the confederation (Stephens, 1986:265). J. Wayne Baker states the close relationship between church and magistracy flowing from Zwingli's views, according to the Swiss model, succinctly:

Zwingli and Bullinger held to a single sphere rather than to Luther's doctrine of the two kingdoms. Zwingli argued that the elders of the New Testament were the equivalent of the magistrate of his day. The council of the Christian city thus rightfully ruled both the civil community and the church, which were virtually identical (Baker, 1996:324).

\section{The Christian community and the distinction between spiritual and civil government}

In the course of his reforming ministry in Zurich, Zwingli accepted the principle that the Christian prince would be responsible for reforming the church, where the leaders of the church had failed. In terms of his theocratic view of society, Zwingli accepted the principles that preacher and prince are both servants of the kingly rule of God. The immediate implication thus is that church and society are not to be seen as two separate entities - they coincided, so that the community was both church and political community under the rule of God (Z:I 463.10-11), and that minister and magistrate seek to establish that rule, and not that the magistrate is subservient to the church, nor vice versa. 7 Within the city the minister and the magistrate have different tasks and functions which are to be exercised in different ways, the one by preaching and the other by ruling, but both tasks are related and are subjected to the kingship of Christ (Z:I 463.10-11). 8 In practice Zwingli's theocracy was based upon the conviction that the Council of the city of Zurich was to help to reinstate Christ on the throne, and to rule subject to the Word of God and the laws of Scripture (Z:I 558.2-5 and cf. Z:II 317.23-24). Therefore, to Zwingli the Christian community includes both the office of magistracy and of preacher and forms a close unity under the kingship of Christ.

7 On the reipublica Christianae in Zwingli's theology, cf. Z:III 911.30-1, VII 310.27-29. Walton (1967:17-29) is of the opinion that Zwingli's faith in the Christian magistrate and his belief in the corpus christianum is reinforced by, but not dependent on, his study of Erasmus. Through Erasmus, Walton detects a possible influence from Marsilius of Padua and Occam. Like Moeller in Reichstadt und Reformation (1972), he accepts the strong communal character of the urban setting within which Zwingli worked.

8 Also cf. Walton (1967:xi-xxii). For the authority of pastor and magistrate grounded in Christ, cf. Baur (1984:181). 
The function of magistracy is not only to stop unrest and disunity, but temporal rulers should also act in removing members of the church for the good of the church (Z:II 324.11-18 and cf. Z:III 256.25-266.11). In his Divine and Human Righteousness (1523) and An Exposition of the Articles (1523), Zwingli distinguishes between the powers of magistracy and those of the preachers. The preacher is concerned with divine righteousness, and the magistrate with human righteousness; outward matters belong to human righteousness and these are to be left to the magistrate; both magistrate and preacher are subject to the word of God in their actions and functions (Z:III 131.1-4).9 This unity between the offices of magistracy and preacher must be seen against the background of Zwingli's views on the "wholeness of the community", so that government may remove members from the church for the sake of the body (Z:II 324.9-13). In A Commentary (1525), he answers the question how the city differs from the church, by pointing out the inward difference between them. The city may be content if you show yourself a faithful citizen, even if you do not trust in Christ. The life of the city, however, does not differ from the life of the church, in so far as each demands what the other demands, to the extent that he refers to the Christian church as the Christian city (Z:III 867.13-17, 868.15-22). Flowing from this close unity between magistracy and the function of preacher, Zwingli sees mutual functions and duties that make the offices of both indispensable:

In the church of Christ governors and prophecy are both necessary, although the latter takes precedence. For just as man is necessarily constituted of both soul and body, the body being the lesser and humbler part, so there can be no church without government, although government supervises and controls those more mundane circumstances which are far removed from the things of the Spirit (S:IV 60.4-9, quoted in Stephens, 1986:294).

According to Zwingli's theocratic views, both magistracy and the office of preaching serve the kingly rule of Christ - they are mutually involved because of their common service. The offices of magistracy and preacher are both subject to the law of God and as such both have to

9 Therefore, to Zwingli, both are subject to the moral law and the gospel. According to Baker (1996:324): "Zwingli included the moral law within the gospel rather than juxtaposing law and gospel within the two kingdoms as Luther did; Zwingli stated that the moral law was God's will for all people." 
apply God's precepts to the Christian community in their functions of governing. 10

In his theocratic views Zwingli expresses the relationship between magistrate and preacher in the relationship of divine and human righteousness: human righteousness is the direct concern of government given by God, whereas divine righteousness is the concern of the preachers of God's word (Z:II 497.23-498.6). Magistracy can secure human righteousness, but it cannot make men righteous before God; it applies compulsion (which belongs to human righteousness), whereas compulsion does not belong to divine righteousness (and is not used by preachers of the word) (Z:II 327.23-30 and 337.19-338.18). The preaching of God's Word is, however, a service to government, as it helps rulers and subjects by teaching them what is good and what is evil (Z:II 504.8-19).

\section{The office of magistracy}

Different from the secular theories of the absolute power of the king, Zwingli subjects the office of magistracy, according to his Reformational views, to the will and commands of God (Z:II 522.2-6). In effect this means that the Christian community cannot function without the offices of both magistrate and pastor: magistracy must be related to divine righteousness, because magistracy is helped by those who preach God's Word and as such should correspond with God's will and with his commands. 11

The framework within which Zwingli's views on the Biblical idea of magisterial office is formulated includes a number of important principles for understanding the nature and functions of magistracy: the office of magistracy is the direct result of man's sinful nature - if all men gave God what they owe him, we should need neither prince nor ruler (Z:II 305.26-28); the office of magistracy is derived from God, and not from man and his social needs (Z:II 311.22, 487.18-25, 651.22-24). The institution of magistracy is based upon Romans 13 , as proved from the Old Testament (Z:II 311.22, 487.18-25, 651.22-24)); temporal rule is not to be exercised by the bishops, but they should be subject to magistracy

- Christ's submission to magisterial government both in word and deed is

10 For the office of magistracy bound to the law of God in Zwingli's thought, cf. Ludwig Gardauns (1973:20).

11 For the state as institution to operate against man's sinful nature (cf.Baur, 1984: 263266, 451 and Bauer, 1984b:220). 
illustrative in this context (Z:Il 304.8-9). The words "render to the emperor" are interpreted as applying to all rulers and not to the emperor only (Z:II 308.4-9 and II 305.1-16, 498.7-17); magistracy is not simply ordained by God, it also denotes the magistrate being the subject of God - in Old Testament times they were even called gods (Z:II 342.1-4, 492.33-493.3; VII 562.25-29; 565.43-566.1). The magistrate bears the sword in the name of God (Z:II 324.9-11; VI ii 25.18-24); magistrates is accountable to God (Z:II 336.2-5); without government human society would be impossible (Z:Il 487.27-488.8). According to Romans 13 the task of magistracy is to protect the good and to punish evil (Z:Il 328.6329.2); the magistrate must learn from God's law how to formulate his laws and judgements should conform to this law also (Z:II 323.19-325.2, 329.27-330.5). The character of the magistrate is as important as the character of the law he is to uphold - the ruler must be one who knows God and believes in him, otherwise he will not understand the law of nature, which is about the love of one's neighbour (Z:II 329.17-330.16); without the fear of God the magistrate will become a tyrant (Z:III 867.713). There is a distinction between the ruler as private person and as person holding office (cf. Z:II 334.2-23 and II 333.26-334.2). The magistrate has a close relationship with God's people and those who are not believers should not rule over God's people, because magistrates are among the shepherds in the church (Z:IV 58.46-59.2).

\section{Obedience to magistrates and the removal of tyrants from office}

Because magistracy is ordained by God, Christians are under an obligation to obey their authority, which implies obedience to the laws and magistrates of the nation, paying taxes to whom taxes are due, tribute to whom tribute is due, rates to whom rates are due (Z:I 308.29-309.5). Zwingli interprets Paul's statement in Romans 13:1 to mean that every soul is to be subject to the powers that be, including obedience to evil government no less than to good government, because government that is evil also comes from God - evil rulers are to be obeyed where they cannot be removed legitimately, but such obedience is more bearable because God will deliver his people as he delivered Israel from bondage (Z:Il 873.25-37).

Christian obedience takes its example from Christ, who obeyed the authorities and paid tribute, although he had no duty to do so (Z:II 306.311; III 400.30-401.1). Obedience to magistracy fundamentally means obeying God, because magistrates are the servants of God. As far as passive resistance to evil magistrates is concerned, Zwingli explicitly states that when authorities set themselves against God, Christians 
should suffer death rather than obey (Z:II 320.2-13, 493.25-32, 503.2-9, 514.30-515.3; cf. also Baur (1984:181, 261, 351 and 451 f.f.). ${ }^{12}$ To Zwingli the fundamental truth is that Christians must obey God rather than men, implying that God's commands take precedence over other commands (Z:VII 645.25-9; II 320.5-7, 503.7-9, 651.35-652.3). He interprets the New Testament text to the effect that if your eye causes you to sin, pluck it out, and throw it from you - implying that temporal rulers and pastors can be deposed (Z:I 120.31-122.12).

On the issue whether temporal rulers may be killed, Zwingli was not clear. Although killing is implied in the context of his views on the removal of rulers and his conviction that sometimes God intervenes by sending someone to avenge his people, he mostly held the view that such acts are not done on own initiative but because of the working of the Spirit (Z:XIV 565.6-25). The example of Elijah alluded to could also refer to the killing of Ahab and Jezebel (Z:III 449.24-450.2; IX 465.7-10). The fundamental point in Zwingli's approach to resistance to tyranny, however, is clear: tyranny is contrary to the will of God. Such rulers rob the poor through taxes and treat their subjects not as human beings, but as animals, or even worse (Z:II 331.11-13, 338.19-342.6; III 24.15-23, 883.13-15). The question whether individuals could kill such a tyrant was answered, on the one hand, by Scriptural examples, like Moses, where God freed his people by sending them a leader to upset the tyrant (Z:II 311.27-312.7; III 468.12-23, 873.32-7 and 880.16-19). On the other hand, he postulated the principle that the removal of a ruler has to follow a proper procedure and that it is not to be achieved by murder or war or an uprising (cf. Z:II 342.26-28, 334.17-346.13).13 Justification to kill a tyrant by the hand of an individual can, therefore, be found only in the event where such a person is sent by God to liberate his people - the implication being that only where an individual has the calling from God to perform the act of tyranicide, can such an act be justified.14 The problem remains, however, how any person can be sure that such a calling has indeed been issued by God.

12 The norm is always the law of God (cf. Baur, 1984:181, 262).

13 Cf. also Baur (1984:181, 262, 454 f.f.).

14 Cf. Gardauns (1973:20-21) for the view that there are indications in Zwingli's political theology that the people may take the initiative to dethrone a tyrant. Even this is subject to the principle that such a tyrant be dethroned with the help of God. 


\section{The legacy of Zwingli in the political theology of Bullinger and Calvin}

Zwingli's theological views on politics served as the blueprint for both Heinrich Bullinger's and John Calvin's views on political matters in all fundamental respects. These perspectives were carried into the European, English and Scottish Reformational communities outside the sphere of influence of Lutheranism. In the case of Bullinger it was his famous work, the Decades, that primarily introduced Zwingli's views into Reformational circles in Western Europe, England, and Scotland15, while in the case of Calvin his Institutes and abridgements of this work in the course of the sixteenth century, carried his interpretations of Zwingli's political views to countries in Europe. ${ }^{16}$

The basic distinction drawn by Zwingli between spiritual and civil government was also accepted by both Bullinger an Calvin. In the second decade, the seventh sermon, dealing with the fifth precept of the Ten Commandments, Bullinger distinguishes between the offices of magistracy and that of pastor. To Bullinger the offices of magistracy and that of pastor must not be confounded (2:329-330 (decade 2, sermon 7 [II:7] ). The king is not called upon to preach, to baptize, and to minister the Lords supper, "or the priest, on the other side, to sit in the judgment seat, and give judgment against a murderer, or by pronouncing sentence to take up matters in strife" (Bullinger, 2:329 [II:7] ).17 He adds, "The church of Christ hath, and retaineth, several and distinguished offices; and God is the God of order, and not of confusion" (Bullinger, 2:329 [II:7]). The political magistrate, on his part, "is commanded to give ear to the ecclesiastical ruler, and the ecclesiastical minister must obey the political governor in all things which the law commandeth" (Bullinger, 2:329 [II:7]). Calvin draws the same distinction between spiritual and civil government: man is under a twofold government so that "whoever knows how to distinguish between body and soul, between this present fleeting life and that future eternal life, will without difficulty know that Christ's spiritual Kingdom and the civil jurisdiction are things completely distinct"

15 Baker (1996:324) states that though "the influence of Zwingli and Bullinger can also be traced in France, Hungary, and Austria, the main areas where Zwinglianism had an impact were Switzerland itself, the Palatinate, the Netherlands, England, and Scotland".

16 It is interesting to note that despite major differences between Zwingli's and Calvin's theology, the political theory of Calvin was strongly aligned to that of Zwingli (and Bullinger). 
(Inst., 4.20.1 (481)). In the 1585 abridgement of Calvin's Institutes the distinction between magistracy and the office of pastor is translated in terms of a "double government of man" (Inst., 4.20.1 (388)).18 In this abridgement, which had a strong impact on the English-speaking world, the editor summarized the answer to the objection of the Anabaptists in terms of "two governments" that

... are distinguished, they are not contrarie. If the kingdome of God did extinguish this present life, civill lawes should be superfluous. But if it be the will of God that we should bee as pilgrims uppon the earth, those which take away these helpes from man, they take from him his manhood (Institutes [Abridgement], 389).

\section{Magistracy regarded as ordained by God}

Following Zwingli, both Bullinger and Calvin take magistracy to be ordained by God. In his commentary on the first precept of the second table of the Ten Commandments, Bullinger discusses the precepts of the second table against the background of the aim of the second table generally, namely: instructing all men what they owe every one to his neighbour; and how we may in this world live honestly, civilly, and in quiet peace among ourselves" (Bullinge, 2:267 [II:5]). He takes princes and magistrates to be included in the name of parents "for the senators and princes are in the holy scriptures called the fathers and pastors of the people" (Bullinger, 2:268 [II:5]). ${ }^{19}$ Calvin, in his Institutes, regards the office of magistracy to be approved by and acceptable to God, as can be seen from the honourable titles God commends to us, for example, that those who serve as magistrates are called "gods" (Inst. 4.20.4).

Zwingli's views on the office of magistracy being entrusted to magistrates by God to serve Him in their office were followed closely by both Bullinger and Calvin. Similar to Zwingli's distinction between the office of magistracy and the person appointed to such office, Bullinger in the

18 All references to the abridgement of Calvin's Institutes is to the following work: An Abridgement of the Institution of Christian Religion written by M. Ihon Calvin. Wherein Briefe And sound answeres to the obiections of the adversaries are set downe. By William Lawne minister of the word of God. Faithfullie translated out of Latin into English by Christopher Fetherstone Minister of the word of God (Vautrollier, 1585).

19 Bullinger (2:309 [II: 6] ), identifies the term magistratus with the meaning of "assigning the masters, guilders, and captains of the people", bearing also the meaning of princes having dominion, so that magistracy "is an office, and an action in executing of the same. "To Bullinger this means that "magistracy, by the scriptures, may be defined to be a divine ordinance or action, whereby the good being defended by the prince's aid, and the evil suppressed by the same authority, godliness, justice, honesty, peace, and tranquility, both in public and private, are safely preserved." 
Decades states that because God is good, and His purposes directed to the well-being and preservation of men, the "good and healthful ordaining of the magistrate, without all doubt, is of God himself, who is the author of all goodness" (Bullinger, 2:314 [II:6] ). This entails that a distinction be made between the office that is the good ordinance of God, and the evil person who executes that good office (Bullinger, 2:314 [II:6]). Therefore, evil is found in the magistrate, and not the good for which he was ordained, that comes from other causes, and the fault thereof is in the men and persons, who neglect God and corrupt the ordinance of God, and not in God, nor in His ordinance (Bullinger, 2:314-315 [II:6] ). The same approach is to be found in Calvin's views on magistracy being ordained by God. God has entrusted to magistrates the "business of serving Him in their office, and (as Moses and Jehoshaphat said to the judges whom they appointed in every city of Judah) of exercising judgment not for man but for God" (4.20.4, 484-485). Elsewhere Calvin calls on magistrates "to comfort themselves greatly when they ponder in themselves that they are occupied not with profane affairs or those alien to a servant of God, but with a most holy office, since they are serving as God's deputies" (4.20.6, (487)).

Zwingli's strong reliance on the principle that the office of magistracy is subject to the command of God, because power is an ordinance of God, is also recognized by Bullinger and Calvin. In the Decades Bullinger reiterates that magistracy is of God, and that his office is good, holy, pleasing God, just, profitable, and necessary for men (2:314 [II:6]). Rulers who rightly execute their office are the friends and worshippers of God; they are his elect instruments, by whom He works man's health, as are to be seen in the examples of Adam, all the patriarchs, Joseph, Moses, and many others after the time of Christ, who rightly executed the office of magistrates (Bullinger, 2:314 [II:6]). Because every magistrate is ordained by God, and is God's minister, so he must be ruled by God, and be obedient to God's holy Word and commandment, "having evermore an eye unto that, and depending still upon that alone" (Bullinger, 2:334 [II:7]). Calvin similarly stresses that magistrates should be faithful as God's deputies. This consideration ought continually to occupy the magistrates themselves, since it can greatly spur them to exercise their office and "bring them remarkable comfort to mitigate the difficulties of their task, which are indeed many and burdensome" $(4.20 .6,(486))$. If they remember that they are vicars of God, they should watch with all care, earnestness, and diligence, to represent in themselves to men some image of divine providence, protection, goodness, benevolence, and justice" (Calvin, 487). Magistrates are deputies of God, to whom they must hereafter render account of the administration of their charge. If they commit some fault, they are not only wrongdoers to men "whom 
they wickedly trouble, but are also insulting toward God himself, whose most holy judgments they defile" (Calvin, 487).

\section{God's law to be enforced in the Christian community}

Zwingli's concern for the magistrate being subject to both tables of the law, also finds parallels in Bullinger's and Calvin's approaches to the enforcement of God's law in the Christian community. Bullinger sums up the key-elements of the magistrate's office in three points: to order, to judge, and to punish (Bullinger, 2:323 [II:7]). The ordinance of the magistrate is a decree made by him for maintaining religion, honesty, justice, and public peace, and it consists of two points: to order rightly matters of religion, and making good laws for the preservation of honesty, justice, and common peace (Bullinger, 2:323 [II:7]). The care of religion also belongs to the magistrate, and it is not in his power only, but his office and duty also, to dispose and advance religion (Bullinger, 2:323 [II:7]). Where the Word of God is not preached, people decay, but happy is he that keeps the law, meaning that they, who would not have the care of religion to appertain to princes, seeks and brings "in the confusion of all things, the dissolution of princes and their people, and lastly, the neglecting and oppression of the poor" (Bullinger, 2:324 [II:7]). In similar vein, Calvin maintains that Christian princes and magistrates should be ashamed of their negligence if they do not apply themselves to the concern for the maintenance of piety as their first concern $(4.20 .9,(490))$. Holy kings are greatly praised in Scripture because they restored the worship of God when it was corrupted or destroyed, "or took care of religion that under them it might flourish oure and unblemished" (Calvin, 4.20 .9 , (490)). But on the contrary, "the sacred History places anarchies among things evil: because there was no king in Israel, each man did as he pleased" (Calvin, 4.20.9, (490)). As far as the second table is concerned, Calvin maintains that the magistrate should give justice to the poor and needy, and rescue the destitute and needy, and deliver the poor and needy from the hand of the oppressor (Calvin, 4.20.9, (491)). The principle to Calvin is clear that the office of magistracy has the duty of maintaining and promoting justice and piety.

\section{The duty of subjects}

Coming to the duty of the subjects to obey the office of magistracy, both Bullinger and Calvin followed the approach of Zwingli. Referring to 1 Peter 2:17, Bullinger (2:279 [II:5]) discusses the implications of the honour due to the office of magistracy. It has to be acknowledged and confessed that the magistrate's office is ordained by God "for men's commodity, and that God by the magistrate doth frankly bestow on us very many and great commodities (Bullinger, 2:279 [II:5]). For the excellence of their office, 
... which is both the chiefest and the most necessary, God doth attribute to the magistrate the use of his own name, and calleth the princes and senators of the people gods, to the intent that they by the very name should be put in mind of their duty, and that the subjects might thereby learn to have them in reverence (Bullinger, 2:279 [II:5]).

If the prince does faithfully discharge his office in the "commonweal", he heaps up a number of good works and praise that never shall be ended (Bullinger, 2:280 [II:5]). No sedition nor conspiricies ought in any case be moved against him, neither must we curse or speak evil of the magistrate, and if he chances at any time to sin, let us behave ourselves toward him as to our father (Bullinger, 2:280 [II:5]). If it happens that magistrates have the intention to promote religion, to advance common justice, to defend the laws, and to favour honesty, and yet notwithstanding, they are troubled with their infirmities, even with grievous offences, the people ought not therefore to despise them and thrust them beside their dignity (Bullinger, 2:280 [II:5]). The vices in princes ought not to move godly people to rebellious sedition, so long as justice is maintained and good laws and public peace defended (Bullinger, 2:280 [II:5]). Subjects ought to pray earnestly and continually for the magistrate's welfare; they ought to aid him with their help and counsel, so often as the need arises, and every nation should give to his magistrate that which by law, or by custom, or by necessity, it owes to him. Paul the apostle says in this regard: "Give to everyone that which ye owe; tribute to whom tribute belongeth, custom to whom custom, fear to whom fear, and honour to whom honour is due" (Romans 13; Bullinger, 2:281 [II:5]).

Calvin follows the same line of reasoning. The subjects should prove their obedience toward rulers, whether by obeying their proclamations, or by paying taxes, or by undertaking public offices and burdens which pertain to the common defense, or by executing any other commands of theirs $(4.20 .23,(506))$. With reference also to Romans 13: 1-2, subjects are called upon to be subject to principalities and powers, to obey magistrates, to be ready for every good work (Calvin, 4.20.23, (506)). Citing Peter 2:13-14, Calvin calls upon subjects to be subject to every human creature for the Lord's sake, whether it be to the king, as supreme, or unto governors who are sent through him to punish evildoers, but to praise doers of good (Calvin, 4.20.23, (506)). Referring to 1 Timothy 2:1-2, Calvin urges that supplications, prayers, intercessions, and thanksgivings be made for all men, for kings, and all that are in authority, that we may lead a quiet and peacable life, with all godliness and honesty (Calvin, 4.20.23, (506)). Since magistrates cannot be resisted without God being resisted at the same time, even though it seems as if an unarmed magistrate can be despised with impunity, God is still armed to avenge this contempt toward Himself with might (Calvin, 
$4.20 .23,(506))$. Obedience also includes obedience to unjust magistrates (Calvin, 4.20.24, (507)). It is, furthermore, demanded of subjects to obey bad kings as required in Scripture (Calvin, 4.20.26, (508)).

\section{Zwingli's views on tyranny}

Zwingli's classical approach of obedience to tyranny embodies four fundamental aspects:

- Christians are under obligation to obey the office of magistracy because every soul is subject to the powers that be. Such obedience is due to evil government no less than to good government, for God also uses evil magistrates to punish us for our sins and such evil rulers are to be endured until God is pleased with us and therefore removes it (Z:II 311.9-24, 509.28-510.6; III 881.1-4).

- Evil rulers are to be endured when they cannot be removed legitimately, but Christian subjects have the consolation that God will deliver his people as he delivered Israel from Egypt (Z:III 873.25-37).

- One must obey God because magistracy comes from Him and to disobey magistracy is to disobey God. Christian obedience to magistracy is obedience to God. Christians, however, may also disobey because God's commands take precedence over the commands of evil rulers (Z:I 120.31-122.12; II 335.3-8, 344.14-16; VII 645.29; IX 465.11-13).

- Although rulers are not to be killed, it is implied that God may send someone to liberate his people from tyranny, not on own initiative but in response to God (Z:XIV 565.6-25).

\section{Bullinger's approach}

In his approach to the issue of obedience to tyranny, Bullinger accepts the first principle, namely that of obedience to all rulers because sometimes God makes "an hypocrite" to reign:

... the evil magistrate is of God, even as also seditions, wars, plagues, hail, frost, and other miseries of mankind come from the Lord, as punishment of sin and wickedness, which the Lord hath appointed to be executed, as he himself saith: 'I will give them children to be their kings, and infants shall rule them; because their tongue and heart hath been against the Lord' (2:315-316 [II:6]).

Because God is the author of good and not of evil, Bullinger accepts that the good and healthful ordaining of the magistrate is of God Himself God who is the author of all goodness (2:314 [II:6]). Therefore, on the question whether tyrannical magistrates are of God, Bullinger dis- 
tinguishes between the good office of magistracy and the evil ruler in the office (2:314-316 [II:6]).

To Zwingli's second principle, Bullinger responded stating, firstly, that those who are vexed with tyrants, and oppressed with wicked magistrates, should call to remembrance and consider

... what and how great their sins of idolatry and uncleanness are, which have already deserved the revenging anger of their jealous God: and then let them think, that God will not withdraw his scourge, unless he see that they redress their corrupt manners and evil religion" (2:316 [II:6]).

Oppressed people must go about and bring to pass a full reformation of matters in religion, and they must pray continually that God "will vouchsafe to pull and draw his oppressed people out of the mire of mischief, wherein they stick fast" (Bullinger, 2:316 [II:6]). Sometimes God utterly destroys, and sometimes "he chasteneth, untoward tyrants with some horrible and sudden disease: as it is evident that it happened to Antiochus, Herod the Great, ..." and others (Bullinger, 2:318 [II:6]).

Bullinger accepts the third principle in his views on resistance to tyranny, namely to obey God rather than man. This principle of passive resistance to tyranny entails that "we have not in any cause to obey either our parents or magistrate, if they themselves shall do, or else command us to do, the things that are wicked and unjust - we are to obey God more than men" (Acts 5: 29) (2:269-270 [II:5]).

In response to the fourth principle enunciated by Zwingli, Bullinger also makes provision for the possibility that God may stir up "noble captains and valiant men to displace tyrants, and set God's people at liberty; as we see many examples thereof in the books of Judges and Kings" (2:318 [II:6]). Although Bullinger makes provision, in principle, for active resistance to tyranny up to the point of killing tyrants, he qualifies his view by stating that "lest any man do fail to abuse those examples, let him consider their calling by God: which calling if he have not, or else do prevent, he is so far from doing good in killing the tyrant, that it is to be feared lest he do make the evil double so much as it was before" (2:318 [II:6]). Bullinger's position on this aspect is merely an account of the principle of Zwingli that such acts must not be taken on own initiative but in response to God. 


\section{Calvin's approach}

Calvin also fully subscribes to the first principle in Zwingli's approach of obedience to magistracy. Calvin in no fewer than six sections deals with obedience to magistracy and related matters. With hearts inclined to reverence their rulers, the subjects should prove their obedience toward them, whether by obeying their proclamations, or by paying taxes, or by undertaking public offices and burdens which pertain to the common defense, or by executing any other commands of their rulers (4.20.23, (506)). Calvin also states that every soul should be subject to the higher powers, for he who resists authority, resists what God has ordained (Romans 13:1-2) (4.20.23, (506)).

Pertaining to Zwingli's second principle, Calvin emphasised that obedience is also due to the unjust magistrate - also those who are "careless about all those things to which they ought to have given heed, and, far from all care, lazily take their pleasure" (4.20.24, (507)).

Zwingli's third principle is also accommodated by Calvin. Calvin strongly appeals to the principle that obedience to man must not become disobedience to God (4.20.32, (514)). In the obedience which subjects must show to rulers, they are always to make this exception, namely that such obedience is never to lead them away from obedience to God (Calvin, 4.20.31, (513)). The Lord, therefore, is the King of Kings,

... who, when he has opened his sacred mouth, must alone be heard, before all and above all men; next to him we are subject to those men who are in authority over us, but only in him. If they command anything against him, let it go unesteemed (Calvin, 4.20.31, (515)).

According to Calvin no harm is done to the dignity of the magistrate when he is humbled before the supreme power of God (4.20.32, (515)). Daniel denied that he had committed any offense against the king when he did not obey his impious edict, for the king had exceeded his limits, and he had not only been a wrongdoer against men, but, "in lifting up his horns against God, had himself abrogated his power" (Calvin, 4.20.32, (515)). As far as passive resistance to tyranny goes, Calvin therefore maintains the same position as Zwingli and Bullinger, namely that we must obey God rather than men (4.20.32, (515)).

On the fourth principle, Calvin explicitly acknowledges the fact that when God intervenes, it is sometimes by unwitting agents. In this respect Calvin detects a revelation of God's goodness, His power, and His providence $(4.20 .30$, (513)). Sometimes God allows avengers among His servants, and arms them with His command to punish the wicked government and deliver His people, "oppressed in unjust ways, from miserable calamity" (Calvin, 4.20, 30, (513)). Sometimes God directs to 
this end "the rage of men with other intentions and other endeavors" (Calvin, 4.20.30, (513)). So, for example, God delivered the people of Israel from the tyranny of Pharao through Moses (Calvin, 4.20.30, (513)). Calvin also provides for the possibility of such people having the calling to take up arms against kings. Such men, when they had been sent by God's lawful calling to carry out such acts, did not at all violate the majesty which is implanted in kings by God's ordination; "but armed from heaven, they subdued the lesser power with the greater, just as it is lawful for kings to punish their subordinates" (4.20.30, (513)).

Calvin strongly follows the idea of Zwingli that tyrants could be removed from office by relying on the lower magistrates in removing evil rulers. Calvin states that

... we must, in the meantime, be very careful not to despise or violate that authority of magistrates, full of venerable majesty, which God has established by the weightiest decrees, even though it may reside with the most unworthy men, who defile it as much as they can with their own wickedness $(4.20 .31,(514))$.

He adds:

For, if the correction of unbridled despotism is the Lord's to avenge, let us not at once think that it is entrusted to us, to whom no command has been given except to obey and suffer $(4.20 .31,(514))$.

If, according to Calvin, there are now any magistrates of the people, appointed to restrain the wilfulness of kings (as in ancient times the ephors were set against the Spartan kings), they may withstand, in accordance with their duty, the fierce licentiousness of kings (4.20.31, (514)). It is, however, not clear from Calvin's views whether this includes active resistance to the point of killing an evil ruler. He merely adds that "if they wink at kings who violently fall upon and assault the lowly common folk", their "dissimulation involves nefarious perfidy, because they dishonestly betray the freedom of the people, of which they know that they have been appointed protectors by God's ordinance" (4.20.31, $(514)) \cdot 20$

20 Skinner (1978:231) also traces the Calvinist theory of "popular magistracy" to Zwingli's account of "ephoral authorities", that he developed in his work The Pastor, and that he delivered as a sermon in 1523. Although Skinner is still inclined to speak of the pastors as "given by God" to defend the people, he nevertheless cites historical examples of magistrates with the power to check their rulers, who, according to Skinner, "undoubtedly had elective status, including the "ephors in Sparta and the tribunes in Rome'". Zwingli (see Bromiley, 1953:239-279, at 267), draws the ambit of representatives, who may act on behalf of the people, wider by stating that if the ruler or prince "resorts all the more to overweening violence we teach that although his acts 


\section{The issue of tyranny and active resistance}

Although both Bullinger and Calvin build on the political foundations of Zwingli, there is a sharper focus on the issue of killing tyrants in Bullinger's approach than in Calvin's.

- The possibility of removing tyrants by active resistance is, more toned down in the system of Calvin than that of Bullinger.

- Bullinger's more explicit formulation of tyranny as a "develish kind of government" (2:315 [II:6]), and "that tyrants themselves are properly the servants of the devil, and not of God" (2:315 [II:6]), surely voices much stronger moral and religious defiance of tyranny than the formulations of Calvin.

- Calvin's strong emphasis on obedience to good and evil rulers leaves the impression that he somehow is most reluctant to accept the possibility of active resistance to tyranny in whatever form it may be cast. 21

The reason for Calvin's weaker theory of active resistance has to be evaluated in the light of his views on the covenant. It is not coincidental that both Zwingli and Bullinger have much stronger views on covenant and resistance to tyranny than is the case with Calvin. Although both Bullinger and Calvin continued the Reformational political tradition of Zwingli, it was Bullinger with his idea of the Christian community bound by covenant (the idea of the covenant community) that promoted Zwingli's stronger approach to tyranny.

The following is also to be emphasised concerning the reasons for Calvin's weaker position on active resistance to tyranny as that postulated by Bullinger. Firstly, Bullinger is clear: the covenant is the divine framework for human life, both religious and civil, from the beginning of the world until the last judgment (McCoy \& Baker, 1991:20); God says, "You will keep my covenant, you and your descendants in their generations. Walk before me and be upright" (McCoy \& Baker, 1991: 111). The entire sum of piety consists in the main points of the covenant, that are taught, partly the love of God and partly the love of the neighbour (McCoy \& Baker, 1991:113). This is precisely what is taught by the main points of the covenant - in fact, the Decalogue itself seems

are wicked he must still be obeyed until the Lord removes him from the seat of authority or a way is found whereby those whose duty it is may deprive him of his functions lest aristocracy or democracy should begin to degenerate into conspiracy and confusion". 
to be almost a paraphrase of the conditions of the covenant (McCoy \& Baker, 1991:113). The judicial or civil laws provided rules for the following: the maintenance of peace and public tranquility, for punishing the guilty, for waging war and repelling enemies, for the defense of liberty, of the oppressed, of widows, of orphans and of the fatherland. The making of laws of justice and equity also relates to the purchase, loan, possessions, inheritance, and other legal subjects of this sort and are also included in that very condition of the covenant that prescribes integrity and commands that we walk in the presence of God (McCoy \& Baker, 1991: 113).

To Bullinger the office of magistracy and all other political aspects are included within the covenant and its conditions. The investigation by James B. Torrance (quoted in Neuser, 1990:16) into the role of covenant in Calvin's theology led him to conclude that although

... the seeds of federal theology may be seen in his writings, the federal scheme constitutes at several decisive points such a shift in theology that the latter question (whether he was a covenant theologian) must be answered in the negative

and

... (a)Ithough the concept of 'the covenant of grace' or 'covenant of life' appears frequently in his (Calvin's) writings, particularly in his discussion of the relation between the Old and New Testaments and of baptism and the Lord's Supper, it is in no way a key concept in his theology.

This conclusion is also confirmed by Baker's (1980:198) remark that "Calvin then, like Oecolampadius before him, reffirmed the basic Reformation distinction between law and gospel by means of the Augustinian notion of testament within double predestination". It can safely be stated that Calvin limits references to the covenant almost exclusively to the church and the sacraments.22 Secondly, Calvin never used the idea of the covenant as the basis for his political theory - it was rather the ideas of testament and double predestination that served as the key to all aspects of his theology and his views on Biblical politics. covenant is to be taken mainly in a spiritual sense. Cf. Abridgement 2.10.15. 
7. The Implications of the Zurich tradition of covenant in Reformational political theory

\subsection{Covenant and resistance to tyranny in English Reformational thought}

The influence of Zwingli's (and Bullinger's) theology on the English Reformational tradition was more profound than is sometimes realised. As early as 1543, an English version of the Fidei Ratio was printed in Zurich, followed by further editions in 1543 and 1548 (Locher, 1979:647). John Veron in Worcester was responsible for a translation of the Einleitung in 1550, and in London, in the same year, an English version of the Hirt (Locher, 1979:647) appeared. In 1526 and 1531 the Archbishop of Canterbury prohibited the works of Zwingli, and in 1546 and 1547, Richard Smith objected strongly to the works of Zwingli (Locher, 1979:647). William Tyndale, renowned Bible translator, in 1529 became a follower of Zwingli. His friend and colleague, Miles Coverdale, was also strongly influenced by the Bible translations from Zurich, and Zwingli's translation of the Psalms, through his hand, had a major impact on the Book of Common Prayer (Locher, 1979:648-649). Coverdale was also responsible for the adaptation of the Brevis Commentario, while his English edition of Bullinger's Christlichem Ehestand initiated the tradition of "conduct books" (Locher, 1979:648-649). Locher provides a most illuminating overview of the influence of the Swiss Reformation on English Reformers like John Frith, John Bradford, Hugh Latimer, John Hooper, Thomas Cranmer and Edmund Grindal (Locher, 1979:649640). 23 The English Reformer Jewel is also included by Battles 24 among the "disciples" of Bullinger. The influence of Bullinger on the English Reformation in particular was of vast proportions. It was especially Bullinger who entertained and harboured many English Reformers who fled abroad during the reign of Queen Mary and he maintained a vast correspondence with many of these Reformers. 25

The Convocation of the province of Canterbury, held in 1586, among the "Orders for the better increase of learning in the inferior Ministers",

23 A most important overview of the impact of Zwingli's theology on the English Reformation is to be found in Baker (1996:326). Also cf. Locher (1981), and D' Aubigné (1963:355-357).

24 Institutes, 587, note 291.

25 Decades, editor's "Advertisement", vii. Cf. also the vast correspondence of English authors with Bullinger (cf. Robinson, 1842; Robinson, 1845 \& Robinson, 1846). 
introduced by Whitgift, Archbishop of Canterbury, the direction that every minister

... having cure, and being under the degrees of master of arts, and bachelors of law, and not licensed to be a public preacher, shall before the second day of February next provide a Bible, and Bullinger's Decades in Latin or English, and a paper book, and shall every day read one chapter of the Holy Scriptures, and note the principal contents thereof briefly in his paper booke, and shall every weeke read over one Sermon in the said Decades, and note likewise the chief matters therein contained in the said paper; and shall once every quarter ... shewe his said note to some preacher nere adjoyninge to be assigned for that purpose. 26

Battles in his translation of Calvin's Institutes (Institutes 587, note 291) also confirms that Bullinger's Decades "became highly influential in England ..." (Institutes 587, note 291)

The influence of Zwingli and Bullinger is clearly visible in the political theology of the English Reformers. Different from the Scottish Reformers, who chose for the covenanted Christian community, the English Reformers had a much milder approach to the issue of active resistance to tyranny. A typical example is the approach of Bishop Hooper.

\section{Hooper's view of the covenant}

Hooper assimilated the Swiss views of the covenant in his political theology. In his A Declaration of the $X$ Holie Commandments of Almightie God written Exod. 20. Deut. 5 (Hooper, 1843:249-430), Hooper's covenant views are dealt with within the context of the Ten Commandments. To the question how God and man are knit together and united in one, he answers that it is necessary to know how God and man "was made at one, that such conditions could be agreed upon and confirmed with such solemn and public evidences, as these tables be, written with the finger of God" (Hooper, 1843:255). The contents of this union between God and man are described by Hooper as binding God "to aid and succour, keep and preserve, warrant and defend man from all ill, both of body and soul, and at the last to give him eternal bliss and everlasting felicity" (Hooper, 1843:255).27 On his part man is bound to obey, serve, and keep God's commandments; to love Him, honour Him, and fear Him above all things (Hooper, 1843:255-256). Hooper then adds: "Were there

Decades, editor's "Advertisement".

27 The references to Biblical passages are to Exodus 19; Deuteronomy 4; Matthew 11; John $3,4,5$, and 6 . 
not love and unity between God and man first, the one would not bind himself to be master, neither the other to be servant in such a friendly and blessed society and fellowship as these tables contain" (Hooper, 1843:256). Similar to Bullinger, Hooper (1843:355) includes under the title of parents in the fifth commandment also the "prince or magistrate". The office of magistracy "hath the defence of the country and the people of the same committed unto his charge" (Hooper, 1843:355). The honour due to magistracy is described by Hooper in terms of having

\begin{abstract}
... in estimation, to prefer and extol; and requireth these affections in the heart, and not only external reverence, as be fair words, outward gestures, without the love of the heart; to obey them in all things honest, agreeing with the law of God, not contemn them, neglect them, hate them, or be unkind to them; to help them as we be able, if necessity require; to put our lives for them, and to pay them their due, Rom. XIII., and that without murmur and grudge. For all those that I have rehearsed be as our fathers, and as it were a second God appointed for us upon the earth (Hooper, 1843:356).
\end{abstract}

\title{
The Biblical idea of office in Hooper's theology
}

The implications of the Biblical idea of office in Hooper's theology involve that every man should reverence and honour these superior powers, not for fear, but for love; we should love the superior powers of the earth and be affectionate to them, and obey them in all things that is consonant or not against the law of God. The superior powers should also be affected with love towards their subjects, as the father is towards his son. The work and ordinance of God should be reflected in the dominion, presservation of the good, punishment of evil, advancement of virtue, oppression of vice, and the preservation and wealth of the commonwealth (Hooper, 1843:357). Hooper reminds the reader that magistrates also have their infirmities and that if magistrates "have good councel", and see what is best for the commonwealth, and the people obey it, it is the work of God (Hooper, 1843:358). If rulers happen to fall from God and follow vice, it is not the duty of the subject "straightway to calumniate, speak, move sedition, cast off obedience, love, and fear, that thou owest unto them; but pray for them, study what thou canst to call them again to God; be prone to forget and remit the offence" (Hooper, 1843:358). Hooper has in mind David and Saul who both fell and yet returned to God. The principle involved here is that a distinction must be drawn between the office itself, which is good, and the officer, that is evil (Hooper, 1843:358).

Hooper strongly appeals to subjects to beware of contumacy and disobedience against the superior powers, and to obey them in all things, where they command nothing against God's laws (Hooper, 1843:359). In the case where they instigate the subjects to the transgression of God's 
laws, such rulers are not to be seen as fathers, but strangers, "that would draw us from the obedience of God, which is our Father (Hooper, 1843:359). To Hooper it is not decent that their authority should be above, and God's authority under; for a man's authority depends on God's, "so should it bring men, and lead men to God" (Hooper, 1843:359). What princes and magistrates should be, what their office is towards their subjects, what their reward is when they govern well, is clearly stated in Scripture. What the king should be is written in Deuteronomy 17 (Hooper, 1843:360). This entails that the ruler must love the commonwealth, as the father his children (Hooper, 1843:360). The king is forbidden to multiply horses, and "to carry the people again into Egypt" (Hooper, 1843:361); he should not glory in his own strength, and cause the people to trust in the might of the flesh, as though by man their commonwealth might be preserved (Hooper, 1843:361). The king is forbidden to have many wives, lest they should draw his heart from God (Hooper, 1843:361); neither should he multiply for himself great abundance of gold and silver (Hooper, 1843:361). He should cause an example of Deuteronomy to be written out, and the book should be with him, to read therein all the days of his life, to learn to fear the Lord his God, to observe all the precepts thereof, and to do them (Hooper, 1843: 361).

Regarding obedience to rulers, Hooper rather diplomatically states that Christ differentiates between the two great lords, God and the civil magistrate, stating "that the people should beware they give not the thing that is due to the one unto the other" (Hooper, 1843:364). The conclusion on the implications of the fifth commandment, as stated in his Declaration of the Ten Commandments, is that those whom God has appointed on the earth to rule over others, must be obeyed, reverenced, honoured, and obeyed, with all our fear and love. We should derogate nothing of their dignity with contempt, contumacy or unkindness (Hooper, 1843: 366). The obedience required of the subject towards the office of magistracy involves obedience to be paid not only to the faithful, but also to the infidel and wicked tyrant (Hooper, 1852:54, 80, 102, 104). God will avenge the abuse of His office (Hooper, 1852:104).

It is clear that Hooper only makes provision for passive resistance in the case where the ruler acts contrary to God's Word:

I believe that the magistrate is an ordinance of God set in his church for the defence of the good and godly, and to chasten and punish the wicked: and also to the magistrate must be given tribute, and reverence and obedience in all things that be not in any wise contrary to God's word. And I do understand this not only of the faithful magistrate, but also of the infidel and wicked tyrant, unto whom we must obey as unto the Lord in all things, so that he command nothing contrary to the word 
of God; for then we ought rather to obey God than man, after the example of the apostles Peter and John (Hooper, 1852:53-54).

It is clear from Hooper's approach (like other English Reformers) that they chose the milder option in Zwingli's political theory, much along the lines in which Calvin interpreted the Swiss Reformational views on resistance to tyranny. The reason for this must be sought in the absence of a strong theoretical vision of the covenanted Christian community, as it is manifested in Bullinger's theology. Nowhere in Hooper's approach to politics a direct link exists between the idea of the Biblical covenant, the office of magistracy and resistance to tyranny.

\subsection{The covenanted Christian community and political resistance in the Scottish Reformation}

Locher (1979:651) makes the important observation that before Scotland became Calvinistic after the Confessio Scotica and the decision of parliament in 1560, there are strong indications that Zwinglian influences played no small role in Scotland28. From 1525 the import of heretical publications were prohibited by parliament in Edinburgh (Locher, 1979: 651). In 1562 the priest Ninian Winzett in Lithlingow wrote against Zwingli and Calvin amongst others (Locher, 1979:651). Library catalogues of bishops and private book collections mention the works of Zwingli, Bucer, and Bullinger (Locher, 1979:651). George Wishart was a known supporter of Zwingli. After his yourney through Germany and Switzerland in 1539/1540 he translated the Confessio Helvetica Prior of 1536 from Latin into English (Locher, 1979:651).

\section{John Knox}

John Knox, the leading figure in the establishment of the Reformation in Scotland in 1560 was a student of Wishart (Locher, 1979:651). The impression exists that he initially was a follower of Zwingli, and that he only became stronger Calvinistically orientated after his arrival in Geneva in 1554 (Locher, 1979:651). His dissatisfaction with Bullinger's conservatism probably played a role in this shift in his theology. Nevertheless, his theology remained closely aligned to Bullinger's views, and Bullinger's political views remained an integral part of Knox's political theology. The reason for this is mainly to be found in the major impact Bullinger's views of the covenant had in Knox's theology and his commitment to the idea of the covenanted Christian community. 
Greaves (1980:213) also comes to the conclusion that Knox's concept of the covenant in his work was not patterned after Calvin's thought. Calvin depicts the covenant as God's promise to man, which had been fulfilled in the incarnation, death, and resurrection of Christ. Greaves furthermore writes that Knox dealt with the covenant essentially as a conditional promise calling for man's reciprocal obedience, and that this emphasis on the covenant as contract was made by Zwingli and Bullinger (among others) on the Continent, and by William Tyndale, John Hooper, and others in England. Greaves (1980:213) concludes that "Knox used the idea of band or covenant ... in his History, but he also developed concepts of the covenant more akin to those found in the Zwingli-Bullinger and Tyndale traditions". Greaves then continues with the following most important statement:

Knox's earliest concept of the covenant was that of an individual engaging in a reciprocal contract with God. Yet the individual is not isolated; he is one of a number of believers acting in concert, though not as a nation (Greaves, 1980:213).

The truth of what Greaves writes and the political implications thereof are proved from Knox's writings and are far-reaching. To Knox the Christian community is bound to God by way of the covenant. The gist of Knox's thought on the covenant is to be found in his Admonition or Warning That the Faithful Christies in London, Newcastel, Barwycke \& Others, May Auoide Gods Vengeance, published in 1554 (Laing, 1854a:161-215). Knox states that this

$\ldots$ is the league betuixt God and us, that He alone sall be our God, and we salbe his pepill: He sall communicat with us of his graces and gudness; We sall serve him in bodie and spreit: He salbe oure saifgard frome death and dampnatioun; We sall seik to him, and sall fie frome all strange Godis (Laing, 1854:190-191).

In the making of this league the faithful solemny swear never to have fellowship with any other religion, except with that which God has confirmed in his word (Laing, 1854:191). Knox observes that God's justice is infinite and immutable, requiring obedience in matters of religion from all who are in this covenant, "in all ageis, that He requyris of any one natioun, or of any particular man in any age befoir us" (Laing, 1854:191). All who are in this covenant form one body: "For all that be in this league ar one bodie, as Moses doth witness, recompting men, wemen, childrene, servandis, princes, preastis, reularis, officeris, and strangers within the Covenant of the Lord ..." (Laing, 1854:191). The immediate implication is that if there is one body there must be one law, so that whatever God requires of one, he requires the same of all in terms of his law (Laing, 1854:191). 
It is noteworthy that, different from Calvin, Knox developed the covenant concept largely in a political context, and then also applied it to the sacrament of baptism (Greaves, 1980:118). 29 In his earlier writings, like his Admonition or Warning, Knox appealed to Christians who had made a covenant with God in which they committed themselves to avoid the worship of false gods, never to have fellowship with any religion not expressly confirmed by Scripture. The covenant duties did not, however, include active resistance (Laing, 1854b:166). Knox points out that although abominable idolatry may triumph for the moment, yet God will avenge their idolatry:

Thair cities salbe brunt, thair land salbe laid waist, thair enemyis sall dwell in thair strangholdis, thair wyffis and thair dochteris salbe defyllit, thair children sall fall in the edge of the sworde; mercie sall thai find none, because thai haif refusit the God of all mercie, when lovinglie and lang he called upon thame (Laing, 1854:167).

In his Letters to His Brethren, and the Lords Professing the Truth in Scotland of 1557 (Laing, 1854b:285), Knox wrote that Christians are lawfully bound to defend their brothers from persecution and tyranny against princes or emperors,

... to the uttermost of your power, provyding alwayis, as I haif said, that nether your self deny lawfull obedience, nethir yit that ye assist nor promot thois that autority and pre-eminence of warldlie glorie, yea, of the oppressioun and distruction of uthiris: ... (Laing, 1854a:285).

He also subscribed to the principle that the nobility have the duty to overthrow an idolatrous sovereign. In his The First Blast of the Trumpet against the Monstrous Regiment of Women, secretly published in 1558, he demanded of them to

... acknowledge that the Regiment of a Woman is a thing most odiuous in the presence of God; they must refuse to be her officers, because she is a tratoresse and rebell against God; and finallie, they must studie to represse her inordinate pride and tyrannie to the uttermost of their power (Laing, 1854:415).

Knox also includes the right of the people in this regard, giving the estates and the people the duty to remove "fromo honor and authoritie that monstre in nature ..." (Laing, 1854:416). On the basis of the right of

29 Cf. Greaves (1980:123) where the author points out that the use of the covenant theme in An Admonition or Warning resulted from contact in Edwardian England with the views of John Hooper. As a disciple of Bullinger, Hooper - like Tyndale emphasized the contractual nature of the covenant. God's promises were conditional on man's obedience. These conditions are set forth in the Ten Commandments. 
the representatives of the people and the people in the covenanted Christian community to punish idolatry even with death, it was a short step for Knox to demand of the people to avenge such idolatry. In his Appellation, which appeared in 1558, Knox demanded from the people to avenge the idolatry of transgressors of God's commands:

Evident it is, that no estate, condition, nor honour, can exempt the idolatour from the handes of God, when he shall call him to accomptes, or shall inflict punishment upon him for his offence: how shall it then excuse the people, that they according to Goddes commaundement punish not to death such as shal solicitate or violently draw the people to idolatrie? (Laing, 1854:500).

With the possibility open for subjects to kill tyrants as a measure of active resistance to tyranny, other political authors, like John Ponet and Christopher Goodman, soon followed in Knox's wake. Hereby they gave rise to a political tradition of resistance to tyranny, quite different from that of the English Reformers, who chose passive resistance in particular circumstances only.

\section{Conclusion}

In 1938 W.A. Dunning (1938:23) wrote that the

... importance of Huldrych Zwingli, the Swiss Reformer, from the standpoint of political theory, is not great, and as such as it is, it appears rather in the method through which the new faith and practice were actually introduced than in the doctrines on which they rested.

From the political views of Zwingli and the influence he exerted, this statement by Dunning appears to be a highly uninformed opinion, based upon very little fact. Within a political context, Dunning, however, is correct by asserting that it "will always be his greatest title to fame that he founded the creed and inaugurated the movement which won the support of ... the Frenchman, John Calvin" (Dunning, 1938:25). From the sources and the lines of influence, it may safely be stated that both Bullinger and Calvin were children of the Swiss Reformation, inaugurated by the brilliant Reformer Huldrych Zwingli. Although Calvin became opposed to some aspects of Zwingli's theology, he largely remained faithful to the basic tenets of Zwingli's political thought.

The political theology of Huldrych Zwingli served as the foundation on which the Reformational views beyond the sphere of influence of Lutheranism arose. All the major elements of Zwingli's political theology are to be found in the later Swiss and Genevan Reformations. Not only did the Zwinglian views permeate the European continent, but they were 
also transplanted to England and Scotland, mostly as a result of the influence of Heinrich Bullinger's theologico-political federalism.

Two different Reformational political traditions arose in England and Scotland, both based upon the pioneering work done by Zwingli. One of the major differences between these two traditions concerns the issue of active resistance to tyranny. Although the English tradition of John Hooper and others also applied the covenant perspective of Bullinger, it did not adequately accommodate the perspective of the covenanted Christian community. The result was similar to that of Calvin on the matter of active resistance to tyranny, namely a weak view of active political resistance. On the other hand, the Scottish tradition of John Knox, Ponet and Goodman saw active political resistance as a direct result of the covenanted Christian community subject to the law of God.

Perceptions about the originality and impact of Calvin's views on political issues need to be reconsidered. In the Battles translation of Calvin's Institutes (4.20.31, (652) ), it is implied that Calvin's views on overturning intolerable governments through the legitimate representatives of the people, are ideas which originated with himself, and that his influence can be traced in John Ponet's radical Shorte Treatise (1556), George Buchanan's De Jure regni apud Scotos (1579), Samuel Rutherford's Lex, Rex (1644), and the Politice Methodice Digesta of Johannes Althusius. It is often not realized that the origin and full meaning of Calvin's political work can only be appreciated within the context of the Zurich Reformation and its idea of the covenant. Battles also reads too much into Calvin's warning, "Let the princes hear and be afraid", linking Ponet's treaties to these remaks. The truth is that Calvin followed the milder approach to resistance to tyranny and, without the idea of the covenanted Christian community, aligned himself to the position of the English Reformers on these issues. The best summary of Calvin's position is to be found in the 1585 English abridgement of his Institutes (4.20.31, (397) ):

Notwithstanding the Lorde did execute his will, when he brake the bloudie sceptres of kings and overthrewe their untollerable gouerments.

Therfore let us neuer despise or offend the reuerent authoritie of the Magistrate. I speake of private persons.

\section{Bibliography}

BAKER, J.W. 1980. Heinrich Bullinger and the Covenant: The Other Reformational Tradition. Athens/Ohio : Ohio University Press.

BAKER, J.W. 1996. Zwinglianism. (In The Oxford Encyclopedia of the Reformation.

Part IV. New York/Oxford: Oxford University Press. p. 323-327.)

BAUR, A. 1984. Zwinglis Theologie. Volume I. Hildesheim/Zurich/New York : Georg Olms Verlag. 
BROMILEY, G.W. 1953. The Library of Christian Classics. Volume XXXIV: Zwingli and Bullinger. London : SCM.

BULLINGER, H. 1849-1852. The Decades of Henry Bullinger. 4 vols. Ed. for the Parker Society, Cambridge : s.n.

CALVIN, J. 1998. Calvin's Institutes. (Battles translation). John Calvin Collection on CD ROM. Ages Digital Library.

CALVIN, M.I. 1585. An Abridgement of the Institution of Christian Religion. Wherein Briefe and sound answeres to the obiections of the adversaries are set downe. By William Lawne minister of the word of God. Faithfullie translated out of Latin into English by Christopher Fetherstone Minister of the word of God, Vautrollier.

COTTRELL, J.W. 1971. Covenant and Baptism in the Theology of Huldreich Zwingli. Princetown : University of Princetown. (Dissertation.)

D' AUBIGNÉ, J.H.M. 1963. The Reformation in England. Ed. by S.M. Houghton. London : Banner of Truth Trust.

DUNNING, W.A. 1938. A History of Political Theories from Luther to Montesquieu. New York : Macmillan.

GARDAUNS, L. 1973. Die Lehre vom Widerstandsrecht des Volks gegen die rechtmässige Obrigkeit. In Luthertum und im Calvinismus des 16. Jahrhunders. Darmstadt : Wissenschaftliche Buchgesellschaft.

GREAVES, R.L. 1980. Theology and Revolution in the Scottish Reformation. Grand Rapids, Michigan : Christian University Press.

HOOPER, J. 1843. Early Writings of John Hooper. Ed. for the Parker Society by Samuel Carr. Cambridge: Cambridge University Press.

HOOPER, J. 1852. Writings of bishop Hooper. Ed. for the Parker Society by Charles Nevinson. Cambridge: Cambridge University Press.

LAING, D., ed. 1854. The Works of John Knox. Volume III \& IV. Edinburgh : s.n.

LOCHER, G.W. 1979. Die Zwinglische Reformation im Rahmen der europaischer Kirchenschichte. Gottingen/Zurich : Vandenhoeck/Ruprecht.

LOCHER, G.W. 1981. Zwingli's Thought: New Perspectives. Studies in the History of Christian Thought, no. 25. Leiden : s.n.

McCOY, S. \& BAKER, J.W. 1991. Fountainhead of Federalism. Heinrich Bullinger and the Covenantal Tradition. (With a translation of De testamento seu foedere Dei unico et aeterno (1534) by Heinrich Bullinger.) Louisville, Kentucky : Westminster/John Knox Press.

MOELLER, B. 1972. Reichstadt und Reformation. (Gütersloh.) Trans. as Imperial Cities and the Reformation. Philadelphia : s.n.

NEUSER, W.H., ed. 1994. The concept of Federal theology - Was Calvin a Federal Theologian? "Calvinus Sacrae Scripturae Professor. Calvin as Confessor of Holy Scripture" - die Referate des Internationalen Kongresses for Calvinforschung. Grand Rapids, Michigan : Eerdmans.

ROBINSON, H., ed. 1842. The Zurich Letters A.D. 1558-1597. Edited for the Parker Society. Cambridge : Cambridge University Press.

ROBINSON, H., ed. 1845. The Zurich Letters. (Second Series.) A.D. 1558-1602. Edited for the Parker Society. Cambridge : Cambridge University Press.

ROBINSON, H., ed. 1846. Original Letters Relative to the English Reformation. Edited for the Parker Society. Cambridge : Cambridge Univresity Press.

$\mathrm{S}$

see ZWINGLI, H. 1828-1842

SKINNER, Q. 1978. The Foundations of Modern Political Thought. Volume Two: The Age of Reformation. London/New York/Melbourne : Cambridge University Press. STEPHENS, W.P. 1986. The Theology of Huldrych Zwingli. Oxford : Clarendon. 
WALTON, R.C. 1967. Zwingli's Theocracy. Toronto : University of Toronto Press.

ZWINGLI, H. 1828-1842. Works. Erste vollständige Ausgabe durch Melchior Schuler und Joh. Schultess, 8 vols. Zurich : s.n.

Z

see ZWINGLI, H. 1905-

ZWINGLI, H. 1905-. Sämtliche Werke. Berlin/Leipzig/Zurich : s.n.

\section{Kernbegrippe:}

Calvyn

federalisme

verbond

Zwingli

Key concepts:

Calvin covenant

federalism

Zwingli 